\title{
Comparison between effectiveness of intramuscular and intravenous lignocaine on ventricular arrhythmia complicating acute myocardial infarction
}

\author{
L. Rydén, A. Waldenström, L. Ehn, ${ }^{1}$ S. Holmberg, and M. Husaini ${ }^{2}$ \\ From the Division of Cardiology, Department of Medicine, Sahlgrenska Hospital, Göteborg, Sweden
}

Forty-three patients with acute myocardial infarction were treated with lignocaine after developing certain ventricular tachyarrhythmias.

Eighteen patients received intravenous treatment: $75 \mathrm{mg}$ as an intravenous bolus immediately followed by an infusion of $2 \mathrm{mg} / \mathrm{min}$, and 25 received intramuscular treatment: $300 \mathrm{mg}$ (3 $\mathrm{ml} 10 \%$ solution) in the lateral vastus muscle. The analysis of arrhythmias was based upon a continuous electrocardiogram. Blood levels of lignocaine were estimated at different times from 10 to 180 minutes after injection. The first two hours after lignocaine administration were used for comparison. There was no significant difference in the occurrence of ventricular tachyarrhythmia between the two groups. Lignocaine blood levels were significantly higher in the intramuscular than the intravenous group at 10 to 60 minutes after the start of injection. At I 20 minutes there was no difference and at 180 minutes the intravenous group had somewhat higher levels. The intravenous group presented surprisingly low values, with a mean for the group of less than $I \cdot 2 \mu \mathrm{g} / \mathrm{ml}$ during the time studied. The levels reached were below those that have been suggested with the dose of intravenous lignocaine.

From the present study it is concluded that the dose of intramuscular lignocaine used is therapeutically effective against ventricular arrhythmias complicating myocardial infarction. The duration of effectiveness is at least one hour.

Prehospital mortality in acute myocardial infarction is still high (McNeilly and Pemberton, 1968; Fulton, Julian, and Oliver, 1969; Lown and Wolf, 197I; Wikland, 197I).

Ventricular tachyarrhythmia is considered to be the main cause (Pantridge and Geddes, 1967; Scott, 1970). The early administration of lignocaine has been suggested as one possible solution to this problem (Scott et al., 1968; Levine, 1969; Lown and Wolf, 197I). It is possible to achieve what are considered therapeutic blood levels of lignocaine, $\mathrm{I} \cdot 2$ to $5.0 \mathrm{\mu g} / \mathrm{ml}$ (Harrison and Alderman, 1972) after intramuscular administration (Scott et al., 1968; Meyer and Zelechowski, I97I; Cohen at al., I972; Zener et al., 1973). Rydén et al. (1972) proposed that $300 \mathrm{mg}$ lignocaine of a 10 Received 14 May 1973.

${ }^{1}$ Present address: Department of Medicine, Karolinska Hospital, Solna, Sweden.

${ }^{2}$ Present address, Ashton-Under-Lyne General Hospital, Lancs. per cent solution given into the lateral vastus muscle should be investigated for its clinical effect. With this amount of the drug, satisfactory blood levels were achieved from between 10 to 15 minutes after the injection for up to 90 to 120 minutes. In the present study intramuscularly administered lignocaine has been compared with intravenously administered lignocaine in patients with ventricular tachyarrhythmia complicating acute myocardial infarction.

\section{Subjects and methods}

Patients admitted to the coronary care unit because of proven or suspected acute myocardial infarction were taken into the study if they developed ventricular tachyarrhythmia of one or more of the following types: I) $\geqq 5$ ventricular ectopic beats/min; 2) paired ventricular ectopic beats; 3) multifocal ventricular ectopic beats; 4) $R$ on $T$ ventricular ectopic beats; and 5) ventricular tachycardia defined as 3 or more ventricular ectopic beats in sequence. 
The presence of one or more of those arrhythmias will be referred to as 'significant ventricular tachyarrhythmias'. Patients with second or third-degree atrioventricular block and those already on antiarrhythmic treatment before admission to the coronary care unit were not accepted. According to date of birth the patients were given either intramuscular or intravenous lignocaine treatment Xylocain $^{\mathrm{R}}$, ASTRA, Södertälje, Sweden). Intravenous treatment consisted of $75 \mathrm{mg}$ lignocaine during 2 minutes immediately followed by a constant infusion of $2 \mathrm{mg}$ per minute by means of an infusion pump. ${ }^{1}$ A 2 per cent lignocaine solution was used. The infusion was given into an arm vein through a short polythene cannula. The patients in the intramuscular group received $300 \mathrm{mg}$ lignocaine as $3 \mathrm{ml}$ of a ro per cent solution as a single injection into the lateral vastus muscle. The site of injection was not massaged. Informed consent was obtained from all patients.

Except for antiarrhythmic treatment the patients were handled, and electrocardiographically monitored according to the routine procedure in the coronary care unit (Henning and Holmberg, 197I). The occurrence of significant ventricular tachyarrhythmias was discovered by this routine monitoring. During the study monitoring was continued and judgement concerning further treatment of a patient was based on this routine arrhythmia detecting system. In parallel the electrocardiogram was continuously recorded using a multichannel ink-writing recorder (Mingograph 81, Elema Schönander AB, Sweden) with a paper speed of ro $\mathrm{mm}$ per sec. This electrocardiographic record was used for the subsequent arrhythmia analysis. All data concerning the occurrence of ventricular tachyarrhythmias refer to this truly continuous electrocardiogram. This method of arrhythmia detection has earlier been described in detail by Mogensen (1970).

After the initial lignocaine administration no further antiarrhythmic treatment was allowed for 30 minutes unless a continuous ventricular tachycardia worsened the clinical condition of the patient or ventricular fibrillation occurred. Thereafter, the amount of lignocaine could be increased if indication for treatment was still present and the doctor on duty considered further treatment necessary. Such patients were subsequently excluded from the study.

All electrocardiograms were analysed minute by minute. The I-minute intervals were classified with regard to the presence or absence of significant ventricular tachyarrhythmias, and of less than 5 ventricular ectopic beats/minute. The number of minutes with the various ventricular tachyarrhythmias was then estimated during successive 15-minute and I-hour periods and expressed as a percentage. Another analysis was based on the number of patients remaining free from significant ventricular arrhythmias at the end of every consecutive I5-minute period expressed as a percentage of the total number of patients in each of the two groups. All patients were included irrespective of occurrence of arrhythmias until the end of 30 minutes.

Venous blood samples were taken at $10,15,30,60$,

${ }^{1}$ Perfusor, Braun, Melsungen, West Germany.
I20, and 180 minutes after the start of injection of lignocaine. The blood was withdrawn from an arm vein on the contralateral side when intravenous lignocaine was used. The blood was frozen at $-16^{\circ} \mathrm{C}$ and sent to the ASTRA Laboratories, Södertälje, Sweden, for lignocaine determinations according to Svinhufvud, Ortengren, and Jacobsson (I965), with some modifications (Rydén et al., 1972). The lignocaine levels were expressed as anhydrous lignocaine base $\mu \mathrm{g} / \mathrm{ml}$ whole blood.

Blood samples were taken during the study for determination of SGOT, SGPT, LDH isoenzymes, serum bilirubin, potassium, and serum creatinine.

The statistical analyses were performed on an Olivetti calculator using $\chi^{2}$-test and Student's t-test.

\section{Results}

Altogether 51 patients were taken into the study, of whom 8 did not fulfil the World Health Organization (1970) criteria of acute myocardial infarction and thus were excluded. Of the remaining 43 patients, 18 belonged to the intravenous and 25 to the intramuscular group. Various characteristics of the patients are presented in Table $\mathrm{I}$. There were no significant differences between the two groups. In Table 2 the different types of significant ventricular arrhythmias in the individual patients are shown. In some patients more than one indication for treatment was present.

Blood levels of lignocaine are presented in Fig. I and Table 3. The intramuscular group had significantly higher lignocaine blood levels at 10, 15, 30, and 60 minutes after the start of injection. At 120 minutes there was no difference between the two groups, and at 180 minutes the intravenous group had higher levels than the intramuscular. Only 3 patients in the intravenous group had reached or exceeded the $I \cdot 2 \mu \mathrm{g} / \mathrm{ml}$ level at I2O minutes after the injection. At 180 minutes the corresponding figure was 7 patients. In the intramuscular group there were 3 patients who never reached a lignocaine blood level $\geq \mathbf{I} \cdot 2 \mu \mathrm{g} / \mathrm{ml}$. Two of those had a peak level of $I .0 \mu \mathrm{g} / \mathrm{ml}$ and one reached $0.6 \mu \mathrm{g} / \mathrm{ml}$. The highest lignocaine level reached in the intramuscular group was $3.5 \mu \mathrm{g} / \mathrm{ml}$.

The effectiveness of lignocaine on ventricular arrhythmias is presented in Fig. 2-5. During the first 2 hours, I patient was excluded from the intravenous group (at 20 minutes) and 5 from the intramuscular group (at 40,60, 70, 75, and 100 minutes). The 6 patients excluded did not show any features in common and did not differ from the groups as a whole. Blood levels of lignocaine among these 6 were not different from the levels in the respective treatment groups. After 2 hours there was a rapid increase in the number of patients excluded from 
TABLE I Clinical and laboratory findings in intravenous and intramuscular groups

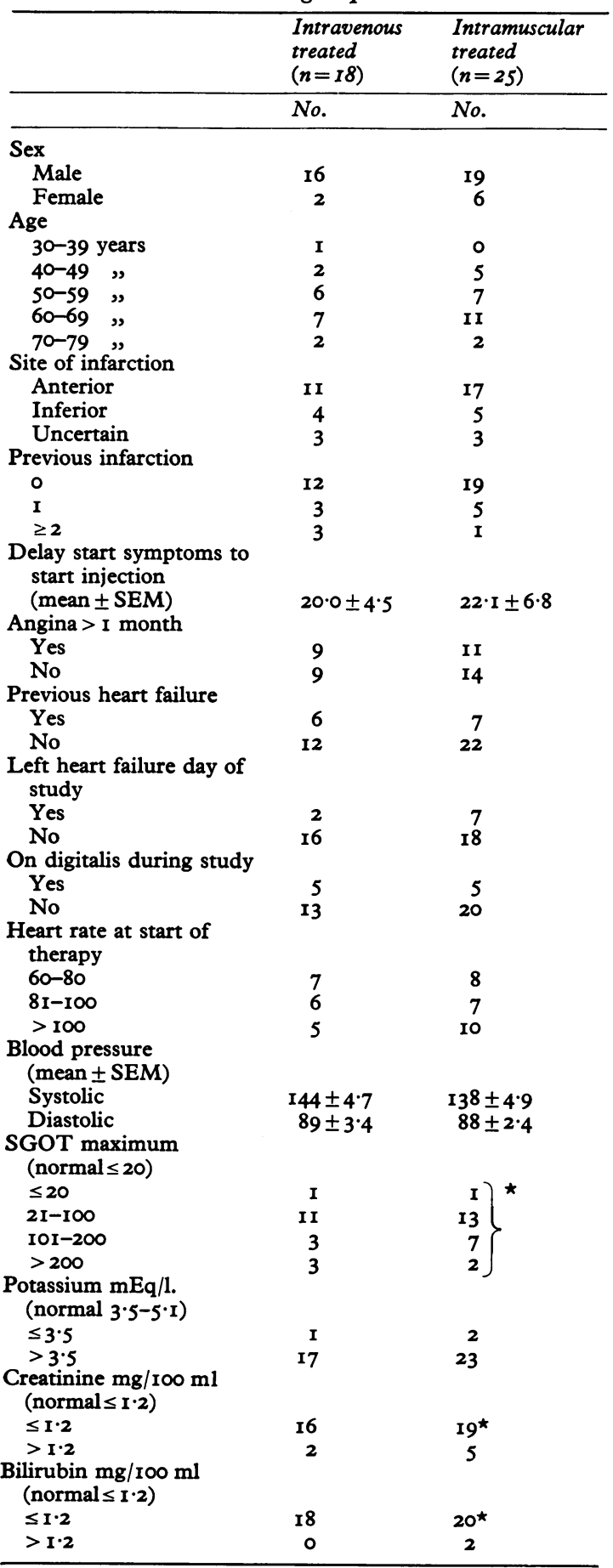

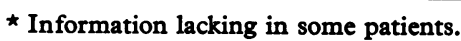

TABLE 2 Types of ventricular arrhythmias in the treatment groups

\begin{tabular}{llll}
\hline $\begin{array}{l}\text { Type } \\
\text { of ventricular } \\
\text { ectopic } \\
\text { beats }\end{array}$ & $\begin{array}{l}\text { Intravenously } \\
\text { treated } \\
n=18\end{array}$ & $\begin{array}{l}\text { Intramuscularly } \\
\text { treated } \\
n=25\end{array}$ & Difference \\
& No. & \\
\hline $\begin{array}{l}\text { No/min. } \\
\text { Paired }\end{array}$ & 13 & 17 & \\
$\begin{array}{l}\text { Multifocal } \\
\text { R on T }\end{array}$ & 7 & I0 & NS \\
$\begin{array}{l}\text { Ventricular } \\
\text { tachycardia }\end{array}$ & I & 8 & NS \\
& 4 & 4 & NS \\
\hline
\end{tabular}

NS $=$ not significant.

the intramuscular group. Thus only the first 2 hours were used for the time correlated arrhythmia analysis. Fig. 2 shows the percentage of observed one-minute intervals containing ventricular ectopic beats of different types during the first and second hour. There are no significant differences between the two groups in respect of any type of ventricular arrhythmia. Fig. 3 presents the percentage of Iminute intervals within each 15 -minute period containing $\geq 5$ ventricular ectopic beats/minute. There are no statistically significant differences between the intramuscular and the intravenous group. There is a progressive reduction in the number of observed intervals with this type of arrhythmia. In the first I5-minute period $\geq 5$ ventricular ectopic beats/minute were present in both groups in about 20 per cent of the I-minute intervals, diminishing in the second period and reaching about 4 per cent in the third and following periods. The occurrence of the other types of significant ventricular arrhythmias did not differ between the two groups (Fig. 4).

The percentage of patients remaining free from significant ventricular arrhythmias seems to diminish faster in the intramuscular than in the intravenous group (Fig. 5). The difference is, however, not significant at any of the observed times.

The patients in both groups were in good or relatively good circulatory condition, without any obvious signs of hepatic or renal dysfunction (Table I).

\section{Side effects}

Except for slight dizziness after the bolus injection in some of the patients in the intravenous group no side effects were observed after lignocaine injection. None of the patients in the intramuscular group showed any sign of local irritation or experienced discomfort at the site of lignocaine injection. No significant changes in heart rate or blood pressure were observed in any of the groups. The electrocardiographic records did not reveal any 


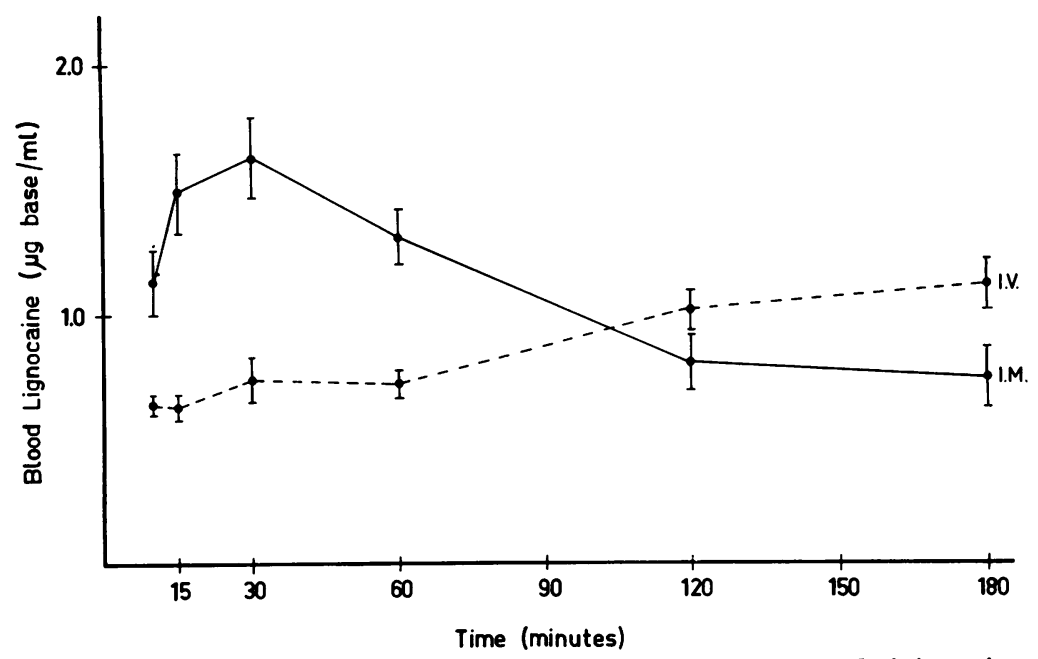

FIG. I Blood levels of lignocaine base (anhydrous) after intravenous administration of $75 \mathrm{mg}$ bolus injection followed by an infusion of $2 \mathrm{mg} / \mathrm{min}$ (dashed line) and $300 \mathrm{mg} 10$ per cent solution in the lateral vastus muscle (solid line). Mean level of the group \pm SEM.

TABLE 3 Blood level of lignocaine

\begin{tabular}{|c|c|c|c|c|c|c|c|}
\hline \multirow{2}{*}{$\begin{array}{l}\text { Group } \\
\text { and } \\
\text { dosage }\end{array}$} & \multirow[t]{2}{*}{$\begin{array}{l}\text { Para- } \\
\text { meters }\end{array}$} & \multicolumn{6}{|c|}{$\begin{array}{l}\text { Lignocaine ( } \mu \mathrm{g} \text { base/ml blood) } \\
\text { Time after injection (min) }\end{array}$} \\
\hline & & 10 & 15 & 30 & 60 & 120 & 180 \\
\hline $\begin{array}{l}\text { Intravenous } \\
75 \mathrm{mg} \text { bolus }+ \\
2 \mathrm{mg} / \mathrm{min} \text { infusion }\end{array}$ & $\begin{array}{l}\text { Mean } \\
\text { SD } \\
\text { SEM } \\
\text { Range } \\
\text { No. }\end{array}$ & $\begin{array}{l}0.64 \\
0.31 \\
0.04 \\
0.4^{-I} \cdot 5 \\
17\end{array}$ & $\begin{array}{l}0.63 \\
0.19 \\
0.05 \\
0.3-1.0 \\
15\end{array}$ & $\begin{array}{l}0.74 \\
0.35 \\
0.09 \\
0.3-1 \cdot 7 \\
16\end{array}$ & $\begin{array}{l}0.72 \\
0.28 \\
0.06 \\
0.3-1 \cdot 0 \\
15\end{array}$ & $\begin{array}{l}I \cdot 01 \\
0.37 \\
0.08 \\
0.4-1 \cdot 2 \\
16\end{array}$ & $\begin{array}{l}I \cdot I I \\
0 \cdot 36 \\
0 \cdot 10 \\
0 \cdot 2-I \cdot 8 \\
15\end{array}$ \\
\hline $\begin{array}{l}\text { Intramuscular } \\
300 \mathrm{mg} \\
\text { M. vastus lat. }\end{array}$ & $\begin{array}{l}\text { Mean } \\
\text { SD } \\
\text { SEM } \\
\text { Range } \\
\text { No. }\end{array}$ & $\begin{array}{l}1 \cdot 13 \\
0.58 \\
0.13 \\
0.1-2.4 \\
21\end{array}$ & $\begin{array}{l}1.49 \\
0.72 \\
0.16 \\
0.3-3.5 \\
20\end{array}$ & $\begin{array}{l}1.63 \\
0.70 \\
0.16 \\
0.6-3.0 \\
20\end{array}$ & $\begin{array}{l}I \cdot 31 \\
0.49 \\
0.11 \\
0.6-2 \cdot 2 \\
20\end{array}$ & $\begin{array}{l}0.80 \\
0.45 \\
0.11 \\
0.3-1.6 \\
16\end{array}$ & $\begin{array}{l}0.74 \\
0.46 \\
0.12 \\
0.3-1 \cdot 5 \\
14\end{array}$ \\
\hline Difference & $\mathbf{P}$ & $<0.001$ & $<0.001$ & $<0.001$ & $<0.001$ & NS & NS \\
\hline
\end{tabular}

supraventricular arrhythmias of importance, asystole, or atrioventricular block of second or thirddegree in any of the groups after lignocaine injection.

\section{Discussion}

Intravenous lignocaine has been shown to be effective against ventricular tachyarrhythmia complicating acute myocardial infarction (Jewitt, Kishon, and Thomas, 1968; Lown and Vassaux, 1968; Spracklen et al., 1968). In many clinics it has become the first drug of choice. Oral and rectal administration is not feasible (Boyes et al., 1971; L. Ehn, 1971, personal communication). A lignocaine plasma level of $\mathrm{I} \cdot 2 \mu \mathrm{g} / \mathrm{ml}$ has been considered the lowest effective therapeutic level (Gianelly et al., 1967). This concentration can be achieved by injecting about $300 \mathrm{mg}$ lignocaine intramuscularly (Scott et al., I968; Meyer and Zelechowski, I971; Cohen et al., I972; Rydén et al., 1972; Zener et al., 1973). Some studies claim effectiveness of intramuscular lignocaine on ventricular tachyarrhythmia (Bellet et al., 1971 ; Bernstein et al., 1972; Fehmers and Dunning, 1972). However, those studies were not controlled, and except for the investigation by Fehmers and Dunning (1972), the aetiology of ventricular tachyarrhythmia was heterogeneous with only some of the patients suffering from acute myocardial infarction.

In intravenous lignocaine treatment a bolus injection of $\mathrm{I} \mathrm{mg} / \mathrm{kg}$ body weight directly followed by a continuous infusion of $\mathbf{2} \mathrm{mg}$ per minute has been recommended (Boyes et al., I97I; Harrison and Alderman, 1972). It has been shown that 


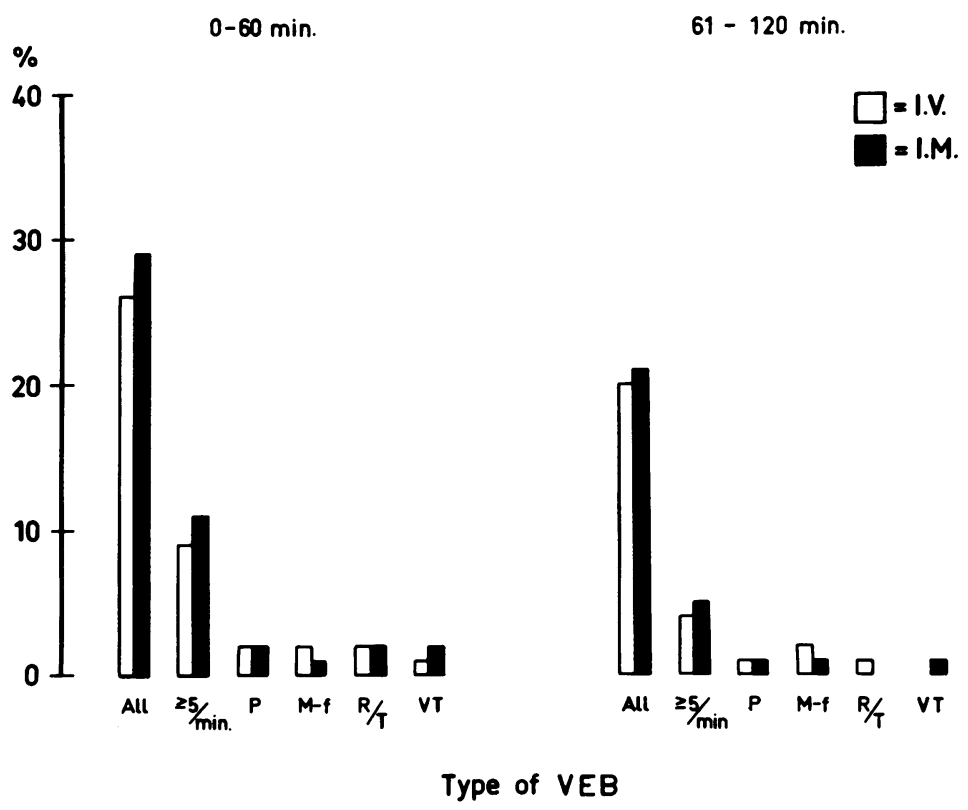

FIG. 2 Percentage of observed one-minute intervals containing ventricular ectopic beats of different types during the first and second hour after start of therapy. All=ventricular ectopic beats of any type including $I$ to 5 ventricular ectopic beats/minute. $P=$ paired ventricular ectopic beats; $M-f=$ multifocal ventricular ectopic beats, $R / T=R$ on $T$ ventricular ectopic beats, $V T=$ ventricular tachycardia.

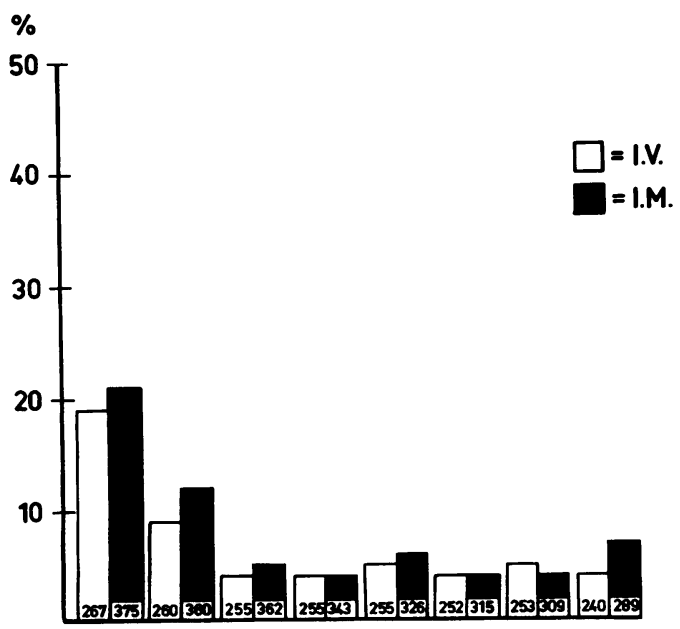

0-15 $16-30 \quad 31-45 \quad 46-60 \quad 61-75 \quad 76-90 \quad 91-105$ 106-120 Min.

FIG. 3 Percentage of observed one-minute intervals with $\geq 5$ ventricular ectopic beats/minute during each 15-minute period. The figures within the lower parts of the bars present the total number of observed $I-$ minute intervals. lignocaine in these dosages has an antiarrhythmic effect when given to patients with acute myocardial infarction as compared with placebo (Mogensen, 1970; Pitt, Lipp, and Anderson, 197I).

The blood level of lignocaine in the intramuscular group agrees well with earlier findings (Rydén et al., 1972). It is known that a bolus injection of the amount used gives initially high, but rapidly decreasing, blood levels (Hayes, 1971; Rowland et al., 197I). It is reasonable to assume that this holds true also in the present study though blood levels were not determined until Io minutes. Direct comparison of the present results with those of others is not easy since published data from continuous observations of blood levels in patients with acute myocardial infarction seem to be lacking. The recommended intravenous dosag? schedule has been based upon results from normal volunteers with the assumption that the distribution volume for lignocaine in patients with myocardial infarction is about half that of normals (Boyes et al., 197I ; Harrison and Alderman, 1972). It has been claimed that lignocaine blood levels above $I \cdot 2 \mu \mathrm{g} / \mathrm{ml}$ should be reached at about 20 

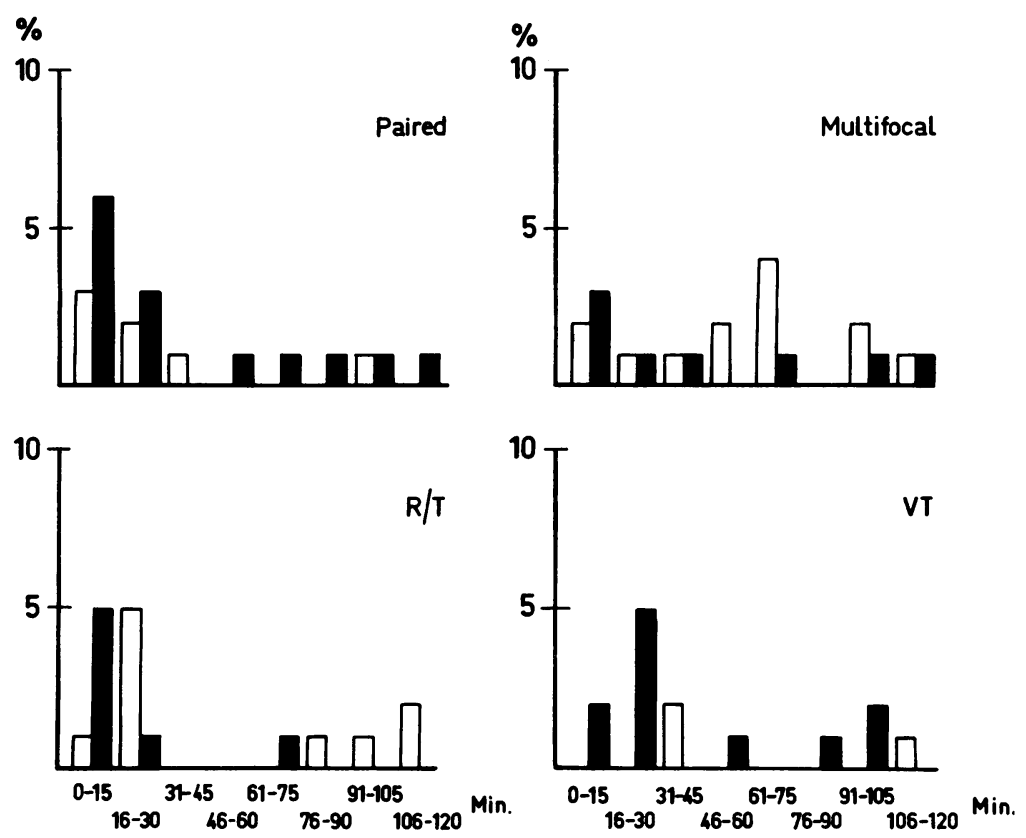

FIG. 4 Percentage of observed I-minute intervals with paired, multifocal, $R$ on $T$ ventricular ectopic beats, and VT=ventricular tachycardia during each 15-minute period.

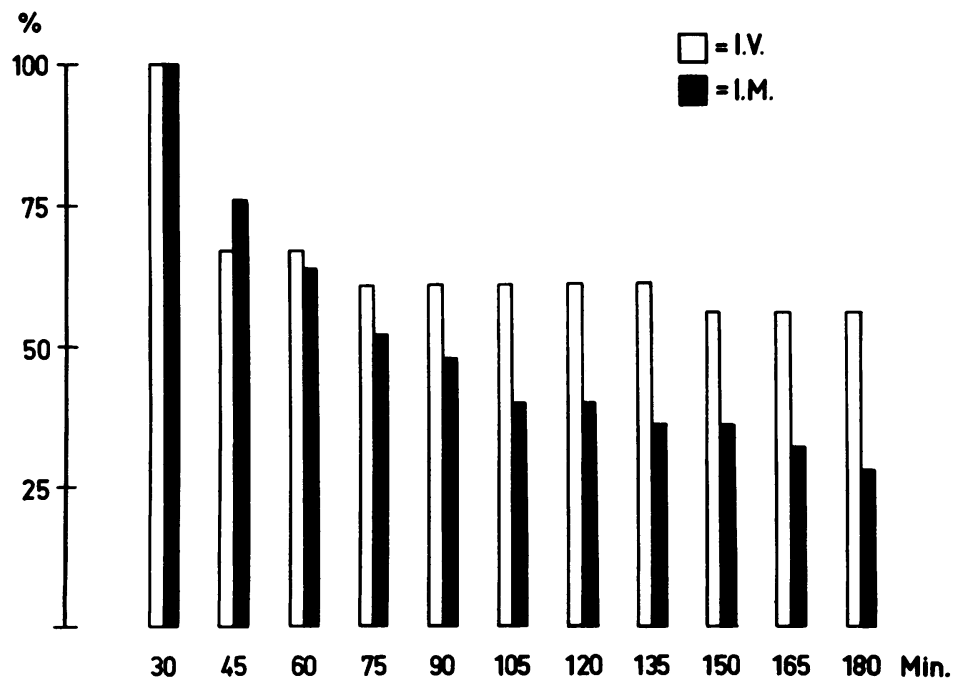

FI G. 5 Percentage of patients remaining totally free from significant ventricular arrhythmias at the end of each I5-minute period. All patients are included at 30 minutes (see text). 
minutes. This was not confirmed by the present study. One explanation could be the lack of agreement concerning the way of expressing lignocaine levels. Some analyses are performed on whole blood (Hayes, 1971 ; Harrison and Alderman, 1972; Rydén et al., 1972) while plasma levels are used by others (Meyer and Zelechowski, 1971; Cohen at al., I972; Bellet et al., I97I). Different factors have been given to convert lignocaine in plasma to lignocaine in blood varying between 0.9 and $I \cdot 0$ (Eriksson, 1966; Katz, I 968; Rowland et al., 1971). Even considering the largest ratio of plasma/erythrocytes this difference cannot explain our low lignocaine levels compared to those predicted. Another source of error is that lignocaine is sometimes determined as lignocaine $\mathrm{HCl}$ and sometimes as lignocaine base. Lignocaine base (anhydrous) equals $0.86 \times$ lignocaine $\mathrm{HCl}$ (anhydrous). Even taking this into consideration, the differences in lignocaine levels are only partly explained. To be able to make future comparisons between different studies, it is necessary to have full details concerning lignocaine determination.

Cardiac insufficiency as well as impaired hepatic function is followed by higher lignocaine blood levels because of a reduced volume of distribution and rate of elimination (Thomson et al., 1969; Stenson, Constantino, and Harrison, 1971). Another explanation for the relatively low blood lignocaine levels is that the volume of distribution and rate of degradation of lignocaine in the present patients is less abnormal than in earlier studies (Boyes et al., 1971; Harrison and Alderman, 1972). No difference in effectiveness on ventricular arrhythmia could be shown between the two groups during the first hour. When interpreting the time correlated arrhythmia analysis, it should be kept in mind that the results can be looked upon as certain only during the first hour. The second hour is more uncertain since a larger number of patients were withdrawn from the intramuscular than from the intravenous group. This exclusion of patients in the intramuscular group might cover a difference between the groups. This problem is eliminated in the patient correlated analysis (Fig. 5). Since maximal lignocaine blood level in the intramuscular group occurred at 30 minutes all patients were included until then whether having had ventricular arrhythmias or not. Though the relative number of patients remaining free from significant ventricular arrhythmias decreased more rapidly in the intramuscular than in the intravenous group the differences were not statistically significant. This is probably explained by the limited number of patients in each group. However, the trend supports the hypothesis that there has been an underestimation of ventricular tachyarrhythmias during the second hour in the time-correlated analysis. Despite higher blood levels at the times of sampling during the first hour after intramuscular lignocaine, this route of administration was not more effective than the intravenous. The high initial peak blood level of lignocaine known to occur after a bolus injection may produce a large and rapidly developing transmembrane gradient of lignocaine. If this is true a more rapid and effective penetration of lignocaine to the target tissues is gained than by a more slowly increasing blood level. After a rapid tissue saturation the blood level might be less important. This could be one explanation for the similar results in the two groups. Keenaghan and Boyes (1972) found a rapid tissue distribution of lignocaine after intravenous injection which also has been suggested by Rowland et al. (I97I).

From the present study it can be concluded that the dose of intramuscular lignocaine used is therapeutically as effective against ventricular arrhythmia complicating acute myocardial infarction as a routinely used dose of intravenous lignocaine. The duration of effectiveness is at least one hour. Though the deltoid muscle is preferred by some authors (Meyer and Zelechowski, 1971; Cohen et al., 1972; Harrison and Alderman, 1972), we still think the lateral muscle of the thigh is a convenient and practical place for injection. This is especially true if injections are to be given by medically unqualified persons such as relatives or ambulance personnel or as autoinjections. The time during which the intramuscular lignocaine was effective seems to be long enough to cover transport to hospital. Based upon this study, it cannot be stated that intramuscular lignocaine will be active as a prophylactic agent in the very early phase of acute myocardial infarction. It has been claimed that lignocaine is less effective during that time (Geddes, Webb, and Pantridge, I972), though controlled studies are lacking. However, preliminary reports of a study by Valentine et al. (1972) suggest that intramuscularly administered lignocaine can be of value in decreasing the early mortality in acute myocardial infarction.

This work was supported by grants from the Swedish Medical Research Council.

The authors wish to thank Dr. Börje Örtengren, ASTRA Laboratories, Södertälje, Sweden, who performed the lignocaine determinations.

\section{References}

Bellet, S., Roman, L., Kostis, J. B., and Fleischmann, D. (197I). Intramuscular lidocaine in the therapy of ventricular arrhythmias. American fournal of Cardiology, 27, 291. 
Bernstein, V., Bernstein, M., Griffiths, J., and Peretz, D. I. (1972). Lidocaine intramuscularly in acute myocardial infarction. Fournal of the American Medical Association, 219, 1027.

Boyes, R. N., Scott, D. B., Jebson, P. J., Godman, M. J., and Julian, D. G. (197I). Pharmacokinetics of lidocaine in man. Clinical Pharmacology and Therapeutics, 12, 105.

Cohen, L. S., Rosenthal, J. E., Horner, D. W., Atkins, J. M., Matthews, O. A., and Sarnoff, S. J. (1972). Plasma levels of lidocaine after intramuscular administration. American Fournal of Cardiology, 29, 520.

Eriksson, E. (1966). Prilocaine. An experimental study in man of a new local anaesthetic with special regard to efficacy, toxicity and excretion. Acta Chirurgica Scandinavica, Suppl. 358, 25.

Fehmers, M. C. O., and Dunning, A. J. (1972). Intramuscularly and orally administered lidocaine in the treatment of ventricular arrhythmias in acute myocardial infarction. American fournal of Cardiology, 29, 514.

Fulton, M., Julian, D. G., and Oliver, M. F. (1969). Sudden death and myocardial infarction. Circulation, 39 and 40, Suppl. IV, I82.

Geddes, J. S., Webb, S., and Pantridge, J. F. (1972). Limitations of lignocaine in control of early ventricular dysrhythmias complicating acute myocardial infarction (abstract). British Heart fournal, 34, 964.

Gianelly, R., von der Groeben, J. O., Spivack, A. P., and Harrison, D. C. (1967). Effect of lidocaine on ventricular arrhythmias in patients with coronary heart disease. New England Fournal of Medicine, 277, 1215.

Harrison, D. C., and Alderman, E. L. (1972). The pharmacology and clinical use of lidocaine as an antiarrhythmic drug-1972. Modern Treatment, 9, 139.

Hayes, A. H. (197I). Intravenous infusion of lidocaine in the control of ventricular arrhythmias. In Lidocaine in the Treatment of Ventricular Arrhythmias, p. 189. Ed. by D. B. Scott and D. G. Julian. E. \& S. Livingstone, Edinburgh.

Henning, R., and Holmberg, S. (1971). Erfarenheter från Sahlgrenska sjukhusets hjärtinfarktavdelning. Läkartidningen, 68, 3603 .

Jewitt, D. E., Kishon, Y., and Thomas, M. (1968). Lignocaine in the management of arrhythmias after acute myocardial infarction. Lancet, $1,266$.

Katz, J. (1968). The distribution of 14 C-labelled lidocaine injected intravenously in the rat. Anesthesiology, 29, 249.

Keenaghan, J. B., and Boyes, R. N. (1972). The tissue distribution, metabolism and excretion of lidocaine in rats, guinea pigs, dogs and man. Fournal of Pharmacology and Experimental Therapeutics, 180, 454.

Levine, H. J. (1969). Pre-hospital management of acute myocardial infarction. American fournal of Cardiology, 24, 826.

Lown, B., and Vassaux, C. (1968). Lidocaine in acute myocardial infarction. Annotation. American Heart fournal, 76, 586.

Lown, B., and Wolf, M. (197I). Approaches to sudden death from coronary heart disease. Circulation, 44, 130.

McNeilly, R. H., and Pemberton, J. (1968). Duration of last attack in 998 fatal cases of coronary artery disease and its relation to possible cardiac resuscitation. British Medical fournal, 3, I39.
Meyer, M. B., and Zelechowski, K. (1971). Intramuscular lidocaine in normal subjects. In Lidocaine in the Treatment of Ventricular Arrhythmias, p. 16r. Ed. by D. B. Scott and D. G. Julian. E. \& S. Livingstone, Edinburgh.

Mogensen, L. (1970). Ventricular tachyarrhythmias and lignocaine prophylaxis in acute myocardial infarction. Acta Medica Scandinavica, 188, Suppl. 513.

Pantridge, J. F., and Geddes, J. S. (1967). A mobile intensivecare unit in the management of myocardial infarction. Lancet, 2, $27 \mathrm{I}$.

Pitt, A., Lipp, H., and Anderson, S. T. (197I). Lignocaine given prophylactically to patients with acute myocardial infarction. Lancet, 1, 612.

Rowland, M., Thomson, P. D., Guichard, A., and Melmon, K. L. (I97I). Disposition kinetics of lidocaine in normal subjects. Annals of the New York Academy of Sciences, I79, 383.

Rydén, L., Wasir, H., Conradsson, T-B., and Olsson, B. (1972). Blood levels of lignocaine after intramuscular administration to patients with proven or suspected acute myocardial infarction. British Heart fournal, 34, 1012.

Scott, D. B., Jebson, P. J., Vellani, C. W., and Julian, D. G. (1968). Plasma-levels of lignocaine after intramuscular injection. Lancet, 2, 1209.

Scott, M. E. (1970). Panel discussion on arrhythmias in acute myocardial infarction. Death outside hospital in AMI: cause and prevention. In Symposium on Cardiac Arrhythmias, p. 71 I. Ed. by E. Sandoe, E. Flensted-Jensen, and K. Olesen. AB Astra, Södertälje, Sweden.

Spracklen, F. H. N., Kimerling, J. J., Besterman, E. M. M., and Litchfield, J. W. (1968). Use of lignocaine in treatment of cardiac arrhythmias. British Medical fournal, $\mathbf{r}$, 89.

Stenson, R. E., Constantino, R. T., and Harrison, D. C. (197I). Interrelationships of hepatic blood flow, cardiac output, and blood levels of lidocaine in man. Circulation, 43, 205.

Svinhufvud, G., Ortengren, B., and Jacobsson, S.-E. (1965). The estimation of lidocaine and prilocaine in biological material by gas chromatography. Scandinavian fournal of Clinical and Laboratory Investigation, 17, 162.

Thomson, P., Conn, K., Steinbrunn, W., Rowland, M., and Melmon, K. (1969). The influence of heart failure and liver disease on plasma concentration and clearance of lidocaine in man (abstract). Circulation, 39, III, 203.

Valentine, P. A., Sloman, J. G., Mashford, M. L., and Frew, J. L. (1972). Double blind trial of lignocaine in acute cardiac infarction. Lecture, VI Congreso Europeo de Cardiologia. Revista Espanola de Cardiologia. Publicacion Oficial de la Sociedad Espanola de Cardiologia. Madrid.

Wikland, B. (197I). Medically unattended fatal cases of ischaemic heart disease in a defined population. Acta Medica Scandinavica, 190, Suppl. 524.

World Health Organization (1970). Report: Ischaemic Heart Disease Registers (EURO 5OIO(4)), pp. 32-33. Copenhagen.

Zener, J. C., Kerber, R. E., Spivack, A. P., and Harrison, D. C. (1973). Blood lidocaine levels and kinetics following high dose intramuscular administration. Circulation. In the press.

Requests for reprints to Dr. L. Rydén, Department of Medicine I, Division of Cardiology, Sahlgrenska Hospital, S-4I3, 45 Göteborg, Sweden. 